SYMBOLAE PHILOLOGORUM POSNANIENSIUM GRAECAE ET LATINAE XXIV/1 • 2014

pp. 97-118. ISBN 978-83-7654-279-9. ISSN 0302-7384

DOI: 10.14746/SPPGL.2014.XXIV.1.7

\title{
ALEKSANDRA SHEASBY
}

Instytut Filologii Klasycznej Uniwersytetu im. Adama Mickiewicza

ul. Fredry 10, 61-701 Poznań

Polska - Poland

\section{POCIESZENIE DLA LIWII PO ŚMIERCI SYNA DRUZUSA (PRZEKŁAD CONSOLATIO AD LIVIAM)}

\begin{abstract}
Sheasby Aleksandra, Pocieszenie dla Liwii po śmierci syna Druzusa (przekład Consolatio ad Liviam) („Consolatio ad Liviam” - a Polish translation).

In the following article, a Polish translation of the anonymous Consolatio ad Liviam is provided, accompanied by an introduction and basic commentary. In the introduction, the historical context of the poem is briefly explained. Moreover the question of the genre, the date and the authorship of the text is discussed, followed by comments on the choice of the form for the translation.
\end{abstract}

Keywords: Consolatio ad Liviam, consolation, epicedion, epicedium, Nero Claudius Drusus, Livia Drusilla, Pseudo-Ovidius.

\section{PERSONAE DRAMATIS}

Kiedy w 38 r. p.n.e. Oktawian August poznał Liwię Druzyllę, największą miłość swojego życia, ta nie tylko była zamężna z Tyberiuszem Klaudiuszem Neronem, z którym miała już jednego syna, ale również nosiła w łonie kolejne jego dziecko. Okoliczność ta nie przeszkodziła jednak Cezarowi poślubić ukochanej. „Szczęściarzom już po trzech miesiącach rodzą się dzieci” - żartowano w Rzymie, kiedy niedługo po ślubie przyszedł na świat Decymus Klaudiusz Neron Druzus. Choć Oktawian podniósł po urodzeniu dziecko, uznając je tym samym za własne, wkrótce chłopiec został odesłany do ojca, gdzie wychowywał się również jego brat Tyberiusz. Dopiero po śmierci ojca kilkuletni Druzus na stałe zamieszkał w pałacu cesarskim.

Wobec braku męskiego potomka August zmuszony był dokonać wyboru odpowiedniego następcy tronu cesarskiego. Najbardziej naturalnym kandydatem wydawał się zięć Oktawiana, Marek Klaudiusz Marcellus, a po jego śmierci

\footnotetext{
${ }^{1}$ Suet. Claud. 1.
} 
kolejny mąż Julii, Marek Agryppa, siostrzeniec cesarza. Kiedy i ten umarł, Liwia dostrzegła szansę zdobycia tronu dla jednego ze swoich synów. W $11 \mathrm{r}$. p.n.e. Tyberiusz zmuszony został do rozwodu z ukochaną Wipsanią Agryppiną i poślubienia Julii.

Choć Tyberiusz był sprawnym wodzem i głównym pretendentem do tronu, to Druzusa ze względu na przystępny charakter i wszechstronne talenty upodobał sobie szczególnie lud rzymski i sam Oktawian. W 19 r. p.n.e. cesarz wymógł na Senacie zgodę, by pasierb rozpoczął cursus honorum o 5 lat wcześniej, niż było to przyjęte. I tak młodzieniec już w wieku 20 lat pełnił funkcję kwestora, następnie przejął pretorskie obowiązki brata na czas jego pobytu w Galii, a po zakończeniu zwycięskiej wojny z Retami, w której sprawował urząd legatus Augusti pro praetore, otrzymał namiestnictwo Trzech Galii, by w 12 r. p.n.e. powrócić do Rzymu i objąć urząd pretora. Następne lata spędził na wyprawach wojennych przeciwko plemionom germańskim, przy czym drugą, w 9 r. p.n.e., dowodził już jako konsul. W drodze powrotnej, świętując kolejny tryumf, spadł nieszczęśliwie z konia, łamiąc sobie nogę, co spowodowało po 30 dniach jego śmierć.

Tyberiusz, dowiedziawszy się o wypadku, natychmiast udał się na spotkanie $\mathrm{z}$ bratem i zastał go jeszcze żywego. Mimo oporu żołnierzy, pragnących pochować Druzusa w miejscu śmierci, przewiózł jego ciało do Rzymu, aby wyprawić mu uroczysty pogrzeb. Po drodze mieszkańcy miast i wsi spontanicznie organizowali procesje, pragnąc pożegnać cieszącego się dużą popularnością konsula, a najznakomitsi obywatele przejmowali od żołnierzy mary. August i Liwia wyszli na spotkanie konduktu aż do Pawii. Podczas ceremonii w Rzymie zarówno Tyberiusz, jak i sam Oktawian wygłosili mowy pogrzebowe, następnie ciało Druzusa spalono, a prochy pochowano w Mauzoleum Augusta. W okolicy założonego przez Druzusa Mogontiacum (obecnej Moguncji) wzniesiono kenotaf, gdzie co roku odbywały się uroczystości ku czci poległego wodza, po którym synowie odziedziczyli przydomek Germanicus.

\section{KONSOLACJA A EPICEDIUM}

Napisane na okoliczność śmierci Druzusa Pocieszenie dotrwało do naszych czasów pod dwoma równoległymi tytułami: Consolatio ad Liviam oraz Epicedion Drusi, z których każdy zwraca uwagę na inny aspekt utworu. Słowo epicedion lub, w przyjętej w języku polskim wersji łacińskiej, epicedium, pochodzące od greckiego epi kedon (,na pogrzebie”, „w żałobie”), oznacza mianowicie pieśń o tematyce żałobnej, ułożoną zazwyczaj w metrum daktylicznym ${ }^{2}$. Consolatio

${ }^{2}$ J. Esteve-Forriol, Die Trauer und Trostgedichte in der römischen Literatur, Diss., Munich 1962, s. 20. 
natomiast określa każdy utwór zawierający element pocieszenia w nieszczęściu, niezależnie od tego, czy będzie to śmierć kogoś bliskiego, wygnanie czy na przykład utrata majątku³. Pojęć tych nie należy zatem utożsamiać, chociaż posiadają one pewien obszar wspólny.

Jedynym kryterium wyznaczającym odrębność literatury konsolacyjnej jest jej wspólna tematyka ${ }^{4}$ Oznacza to w konsekwencji ogromną rozpiętość gatunkową, bo zaliczają się tutaj teksty z obszaru wymowy, filozofii, epistolografii czy poezji. Obok Pocieszenia należałoby więc postawić tak różnorodne utwory, jak Rozmowy tuskulańskie Cycerona, niektóre listy Seneki i Plutarcha, mowy żałobne św. Ambrożego czy pisane w prosimetrum O pocieszeniu, jakie daje filozofia Boecjusza. Szczególną odmianę tego typu literatury stanowi tzw. consolatio mortis - pocieszenie po śmierci kogoś bliskiego, oparte zazwyczaj na nauczaniu którejś ze szkół filozoficznych. Autor utworu konsolacyjnego obierał nieraz dwie niezależne linie argumentacji: z jednej strony tłumaczył, że śmierć nie jest dla zmarłego złem, a wręcz prowadzi do lepszego życia, z drugiej pouczał, że strata poniesiona przez osobę osieroconą jest możliwa do zniesienia. Argumentację ilustrowały zwykle przykłady (exempla) postaci mitycznych i historycznych, które również doświadczyły żałoby po kimś bliskim ${ }^{5}$.

Motywy konsolacyjne pojawiają się również w epicediach, nie są one jednak głównym wyznacznikiem tego typu utworów. Teksty dzielą się bowiem na takie, w których wypowiada się osoba bezpośrednio dotknięta żałobą, oraz te, w których kto inny zwraca się do bliskich zmarłego. Oczywiście im bliżej autor jest związany z adresatem utworu, tym bardziej autentyczna staje się jego wypowiedź; jeśli poeta przemawia do kogoś zupełnie obcego, jego wiersz będzie sprawiał wrażenie jedynie artystycznego popisu, nie zaś prawdziwego pocieszenia. Epicedia pisane we własnym imieniu tchną zazwyczaj pesymizmem, podczas gdy utwory o cechach konsolacji ukazują sytuację w bardziej pozytywnym świetle, starając się złagodzić trudny do zniesienia ból. Wśród prezentowanych sposobów przeżywania żałoby można wyznaczyć pewne toposy, jak bezwarunkowe podporządkowanie się nieuniknionemu, wściekłość i żal do okrutnego losu, nieodparte pragnienie pogrążenia się w rozpaczy lub chęć zamknięcia się w sobie, prowadząca nawet do prób samobójczych ${ }^{6}$.

W Pocieszeniu znajdujemy cechy właściwe obu scharakteryzowanym wyżej pojęciom: tematykę funeralną i formę dystychu elegijnego, typowe dla epicediów, jak również silnie rozbudowany element konsolacyjny. Zabłocki analizuje Consolatio ad Liviam w kontekście tradycji epicedium i elegii żałobnej, charakteryzując ją jako ,utwór przejściowy między tradycyjną rzymską elegią żałobną

${ }^{3}$ L. Małunowicz, Co to jest konsolacja? „Eos” LVII, 1967/68, s. 70.

${ }^{4}$ Ibidem, s. 69.

${ }^{5}$ Brill's Encyclopaedia of the Ancient World New Pauly, t. 3, red. H. Cancik, H. Schneider, Leiden-Boston 2003, s. 705.

${ }^{6}$ J. Esteve-Forriol, op. cit., s. 21-23. 
a retorycznym epicedium Statiusa"7. W tym ujęciu pocieszenie stanowi (obok części ekspozycyjno-laudacyjnej oraz komploracyjnej) element trójczłonowej kompozycji poematu, przewidzianej regułami retoryki.

\section{KOMPOZYCJA UTWORU}

Stosunkowo łatwo jest wyznaczyć granice poszczególnych części poematu: wersy 1-166 obejmują ekspozycję i pochwałę Druzusa, wersy 167-328 wypełnia lament nad zmarłym, a dopiero w wersach 329-474 mamy do czynienia z właściwą konsolacją ${ }^{8}$. Zabłocki ${ }^{9}$ zwraca jednak uwagę, że powyższy podział nie jest absolutny, a poszczególne motywy przenikają się nawzajem i powtarzają w różnych częściach.

Część pierwszą rozpoczyna dwunastowierszowa ekspozycja, skierowana do Liwii. Po niej następuje krótka (13-20) pochwała czynów wojennych Druzusa, której towarzyszy obraz matki wyczekującej powrotu tryumfującego syna (21-36). Nadzieja radości zostaje jednak zniweczona przez smutną rzeczywistość, która wymaga od Liwii poddania się żałobie (37-40). Po wezwaniu do opłakiwania Druzusa autor poświęca wersy 41-58 pochwale nieskalanych obyczajów cesarzowej, które nie chronią jej jednak przed zakusami bezlitosnej Fortuny. Następnie punkt widzenia Konsolatora rozszerza się na dom Cezara (59-72), dotykany wciąż nowymi nieszczęściami. Po wyrażeniu żalu w imieniu ludu rzymskiego (73-76) autor w ogólnych słowach wychwala Druzusa i płynnie przechodzi do ukazania rozpaczy jego brata (77-94) i matki (95-166), gdzie po serii mitologicznych exemplów przemawia sama Liwia (121-166).

Część druga pozostaje, jak zauważa Zabłocki ${ }^{10}$, pod wyraźnym wpływem epiki. Wypełnia ją obszerny opis ludu Rzymu i italskich miasteczek, kiedy ciało Druzusa przybywa z Germanii i witane jest w żałobnym kondukcie. Oprócz mieszkańców opłakują młodzieńca również bóstwa opiekuńcze Rzymu; Konsolator wplata w swój opis scenę, w której bóg rzeki Tyber z rozpaczy leje tak obfite łzy, że miastu grozi powódź, powstrzymuje go jednak Mars (221-252). Po tym wtrąceniu autor wraca do opisu pogrzebu, płynnie przechodząc do ponownej pochwały Druzusa (259-270), a od niej do zapowiedzi zemsty na Germanii, winnej śmierci wodza (271-282) - fragment dość zaskakujący w kontekście przytaczanych w części konsolacyjnej elementów filozofii stoickiej. Raz jeszcze wspomniani są bogowie (tym razem Kastor i Polluks), pogrążony w rozpaczy Tyberiusz, bolejący lud rzymski (283-298), a wreszcie wdowa po

\footnotetext{
${ }^{7}$ S. Zabłocki, Antyczne epicedium i elegia żałobna, Wrocław 1965, s. 136.

${ }^{8} \mathrm{~A}$. Witlox, Consolatio ad Liviam, prolegomenis, commentario exegetico, indice instructa, Maastricht 1934, s. 15.

${ }^{9}$ S. Zabłocki, op. cit., s. 156-157.

${ }^{10}$ Ibidem, s. 142.
} 
zmarłym, do której skierowane są słowa pochwały obojga oraz współczucia (299-328).

W części trzeciej autor wykorzystuje znane toposy konsolacyjne, zbieżne, jak zauważa Zabłocki ${ }^{11}$, z motywami zebranymi w Ad Polybium de consolatione Seneki. Konsolację rozpoczyna wizja Druzusa tryumfującego w Elizjum (329-340), po niej zaś poeta znów zwraca się bezpośrednio do Liwii, nawołując do umiaru w żałobie. Konsolator argumentuje, że: pozycja cesarzowej wymaga stosownego zachowania (343-356), śmierć czeka wszystkich ludzi i cały świat, trzeba zatem troszczyć się przede wszystkim o własny sposób życia (357-364), życie jest zaledwie pożyczką o nieznanym terminie zwrotu (365-374), życzliwość Fortuny okazywana Liwii przez lata przerasta pojedynczą stratę (375-392), cios był złagodzony przez to, że Druzus umierał daleko, a jego śmierć była poprzedzona okresem niepewności (393-400), w dodatku bogowie zesłali znaki zapowiadające nieszczęście (401-410). Po wezwaniu do Tyberiusza, aby ze względu na matkę dożył starości (411-414), Konsolator wspomina o próbie samobójczej Liwii, udaremnionej przez rodzinę (415-426), a następnie przywołuje przykłady postaci mitologicznych i współczesnych, których żal bliskich nie przywrócił do życia (427-442). Wreszcie sam Druzus przemawia do matki, odnosząc się do swoich zasług i nawołując ją do porzucenia nieumiarkowanej rozpaczy (447-468). Na koniec poeta przypomina, że Liwii wciąż pozostaje drugi syn oraz mąż, nie godzi się zatem, aby pozostawała w żałobie (471-474).

\section{KWESTIA AUTORSTWA I DATY POWSTANIA}

Starożytni filologowie jednogłośnie przypisywali Pocieszenie Owidiuszowi. Dopiero w XVI wieku Joseph Scaliger ${ }^{12}$ wyraził wątpliwości co do autorstwa utworu, przyznając je niesłusznie Gajuszowi Albinowanowi Pedonowi, sekretarzowi cesarza Tyberiusza. Sam Konsolator zdaje się w kilku fragmentach utworu świadomie sugerować, jakoby był tożsamy z Owidiuszem: w wersie 202 podkreśla swoją przynależność do stanu ekwickiego, którą chlubił się poeta z Sulmony ${ }^{13}$, w wersie 387 dorzuca odbiegającą od tematu wzmiankę o Poncie, miejscu zesłania Nazona, a cały tekst wypełniają liczne cytaty - wyrażenia, hemistychy, a nawet kompletne wersy - z corpus Ovidianum. Współcześni filologowie są jednak zgodni, że mocno skonwencjonalizowane Pocieszenie dalekie jest od kunsztu genialnego poety z Sulmony. Przeciwko jego

${ }^{11}$ Ibidem, s. 150-151.

${ }^{12} \mathrm{C}$. Pedo Albinovanus, Elegiae III et fragmenta cum interpretatione et notis Jos Scaligeri, Frid. Lindenbruchii, Nic. Heinsii, Theod. Goralli et aliorum, Amsterdam 1703, cyt. za: A. Witlox, op. cit., s. IX.

${ }^{13}$ Ov. Trist. IV 10. 
autorstwu przemawia również brak jakiejkolwiek wzmianki o Pocieszeniu w Owidiuszowych Żalach, a przecież utwór ten mógłby stanowić ważki argument w prośbach o zgodę na powrót do Rzymu. Wygląda zatem na to, że anonimowy poeta po prostu chętnie cytował Nazona (Zabłocki ${ }^{14}$ przypuszcza, że główną inspiracją byłoby niezachowane epicedium Owidiusza na Augusta), wzbogacając zresztą swój tekst o passusy z Katullusa, Tibullusa, Propercjusza, Wergiliusza i wielu innych. Po odrzuceniu dość karkołomnej teorii Vollmera ${ }^{15}$, przypuszczającego, że wygnany poeta mógł wykorzystać fragmenty utworu pisarza popularnego na dworze cesarskim, aby przypodobać się Augustowi, musimy więc wykluczyć autorstwo Owidiusza, chociaż trudno jednoznacznie odpowiedzieć na pytanie, kim jest tajemniczy Konsolator i kiedy mógł napisać swoje dzieło.

Atrakcyjna wydaje się teza o tożsamości naszego poety i autora dwóch innych anonimowych utworów żałobnych odnoszących się do otoczenia cesarza: Elegii do Mecenasa, zmarłego rok po Druzusie. Już zresztą w pierwszym wersie wspomina elegik, że krótko po opłakiwaniu śmierci młodzieńca przystępuje do pochwały starca ${ }^{16}$. Utwory te jednak bardzo się od siebie różnią, zarówno pod względem metryki (w Pocieszeniu elizje pojawiają się kilkakrotnie częściej niż w Elegiach ${ }^{17}$ ), jak stylu i kompozycji, które u Konsolatora prezentują się o wiele lepiej niż w utworach ku czci Mecenasa. Co więcej, w tekstach Elegii znaleźć można cytaty z listu 114a Seneki, co wskazywałoby na powstanie rzeczonych utworów za czasów Nerona, nie zaś - jak sugeruje ich autor - bezpośrednio po śmierci Mecenasa.

Doszukiwano się podobnych powiązań pomiędzy Pocieszeniem a konsolacyjnymi tekstami Seneki. Skutsch ${ }^{18}$ argumentuje jednak, że występujące analogie są raczej dziełem przypadku i wynikają z wykorzystania podobnych toposów przez obu autorów. Możliwe zresztą, że to Seneka, inspirujący się - jak sam zaznacza ${ }^{19}$ - różnymi dostępnymi tekstami konsolacyjnymi, zaczerpnął nieco z Pocieszenia, które mogło być w tamtym okresie utworem całkiem popularnym. Przeciwko tak późnemu powstaniu wiersza - jakkolwiek niektórzy badacze przesuwają je aż do wieków średnich - przemawia również żywy obraz pogrzebu Druzusa, wskazujący na udział poety w ceremonii, oraz silne zaangażowanie Konsolatora w pochwałę Liwii i Tyberiusza, która za panowania

${ }^{14}$ S. Zabłocki, op. cit., s. $154-155$.

${ }^{15}$ E. Baehrens, F. Vollmer, Poetae Latini minores, Leipzig 1910, cyt. za: A. Witlox, op. cit., s. X.

${ }^{16} \mathrm{H}$. Schoonhoven, Elegiae in Maecenatem: prolegomena, textend commentary, I1, Groningen 1980.

${ }^{17}$ R.B. Steele, The Nux, Maecenas and Consolatio, Nashville-Tenessee 1933, s. 27-28, cyt. za: A. Witlox, op. cit., s. XIII.

${ }^{18}$ F. Skutsch, Consolatio ad Liviam, [w:] Paulys Realencyclopädie der classischen Altertumswissenschaft, t. 4, s. 933-934.

${ }^{19}$ Sen. Dial. XI 1. 
Nerona byłaby już bezprzedmiotowa. Nie oznacza to bynajmniej, że za datę powstania Pocieszenia możemy bezkrytycznie przyjąć 9 r. p.n.e., tj. rok śmierci Druzusa. W takim bowiem wypadku niezwykle trudno byłoby wyjaśnić równie częste czerpanie z czwartej księgi Listów z Pontu, powstałej po tej dacie, co z wcześniejszych dzieł Owidiusza. Witlox nie przypuszcza również, by utwór mógł zostać ofiarowany Liwii po śmierci Augusta, wówczas bowiem co najmniej nie na miejscu wydawałoby się końcowe wezwanie do porzucenia żałoby, motywowane pozostawaniem Oktawiana przy życiu. W obliczu tych argumentów autor wnioskuje, że Pocieszenie napisane zostało krótko po śmierci Liwii, a jeszcze za panowania Tyberiusza, jako pośmiertna „laurka” ku czci matki ce$\operatorname{sarza}^{20}$.

\section{UWAGI DO PRZEKŁADU}

Tłumacz starożytnego tekstu poetyckiego musi nieodmiennie stanąć przed wyborem pomiędzy różnymi formami przekładu, zarówno wierszowanego, jak i prozatorskiego. Każda z możliwości ma swoje wady i zalety, a na ostateczną decyzję wpływać będą zawsze - oprócz struktury metrycznej utworu i jego tematyki - również osobiste preferencje tłumacza, co szczególnie podkreślał Jan Wikarjak: „Osobiście postawiłbym tłumaczowi tylko jeden warunek: winien tłumaczyć takim wierszem, jakim umie się posługiwać" ${ }^{21}$. Różnorodność ta znajduje odzwierciedlenie przede wszystkim w najczęściej przekładanych na język polski eposach Homera i Wergiliusza.

Tekst Pocieszenia, pisany dystychem elegijnym, nastręcza jednak thumaczowi więcej problemów, znacznie utrudniając wybór pomiędzy przyjętymi szkołami przekładu. Ze względu na tematykę utworu rezygnuję z możliwości tłumaczenia prozatorskiego. Sprawdza się ono wprawdzie w przypadku spolszczonej przez Jana Parandowskiego Odysei, przypominającej swą formą powieść, czy thumaczonych przez Wandę Markowską Heroid Owidiusza, stanowiących nowatorskie dzieło literackie o charakterze pomysłowego studium psychologicznego, zupełnie by jednak nie odpowiadało skonwencjonalizowanej naturze $P O$ cieszenia, czyniąc je tym samym dość nużącym i trudnym w odbiorze.

Ulubiony natomiast przez tłumaczy dzieł epickich rymowany trzynastozgłoskowiec, jakkolwiek mniej pojemny od heksametru daktylicznego, może go z powodzeniem zastąpić, jeśli przyjmiemy, że przekładowi wolno długością przewyższać oryginał. O wiele trudniej thumaczy się w ten sposób dystych elegijny, w którym każdy dwuwiersz prezentuje najczęściej pojedynczą myśl, przez co przesunięcie końca zdania do następnego wersu burzyłoby kompozycję

\footnotetext{
${ }^{20}$ A. Witlox, op. cit., s. XVII.

${ }^{21}$ J. Wikarjak, Polskie przekłady „Eneidy”, SPhP 3, 1977, s. 130.
} 
utworu. Z kolei rozciągnięcie myśli na dwa dystychy wymagałoby użycia dużej liczby słów, które nie występowały w pierwotnym tekście, prowadząc do zbyt daleko posuniętej jego interpretacji, i dwukrotnie wydłużyłoby go w stosunku do oryginału.

Wydawać by się mogło, że najodpowiedniejszym będzie w tej sytuacji przekład izometryczny, ten jednak ze względu na nagromadzenie wyrazów jednosylabowych, kończących kadencje, oraz występowanie średniówki pomiędzy dwoma sylabami akcentowanymi brzmi w języku polskim nienaturalnie. Jedynie thumacz naprawdę wysokiej klasy, jaką wykazał m.in. Wiktor Steffen w przekładzie elegii zamieszczonych w Antologii liryki aleksandryjskiej, jest w stanie dobrać jednosylabowe słowa tak, by nie narazić tekstu na śmieszność i wyraźnie zaznaczyć miejsce występowania dierezy.

W związku z powyższymi trudnościami zdecydowałam się - nie bez wątpliwości - na przekład „pseudoizometryczny”, sprowadzając całość tekstu do polskiego heksametru, sięgającego swym chlubnym początkiem utworów Mickiewicza i Norwida. Dzięki temu zachowuję w tłumaczeniu liczbę wersów zgodną z oryginałem, nie tracąc przy tym uroczystego ducha utworu konsolacyjnego. W pewnym stopniu usprawiedliwia ten wybór również obserwacja Zabłockiego ${ }^{22}$, że metrum utworu niejako mija się w Consolatio z podejściem do tematu, bliskim epickiemu ujęciu Stacjusza, a wybór dystychu elegijnego byłby podyktowany przede wszystkim poszanowaniem rzymskiej tradycji. Aby choć w niewielkim stopniu odróżnić formę proponowanego przekładu od „Zwykłego" heksametru polskiego, wprowadzam subtelne rozróżnienie między oboma wersami poszczególnych dystychów, umieszczając po średniówce sylabę nieakcentowaną $\mathrm{w}$ wierszu odpowiadającym heksametrowi, a akcentowaną w wierszu reprezentującym pentametr. Dzięki temu pierwszy wiersz zachowuje większą ciągłość wewnętrzną w przeciwieństwie do drugiego, który - podobnie jak pentametr daktyliczny - wyraźnie dzieli się na dwie części. Rozróżnienie to podkreślam również szatą graficzną, poprzez zastosowanie wcięcia na początku co drugiego wersu.

Podobnie jak autor Pocieszenia staram się unikać niepotrzebnego archaizowania przekładu, które mogłoby wywrzeć na czytelniku mylne wrażenie na temat oryginału. Język Konsolatora jest bowiem - w przeciwieństwie np. do homeryckiego - na wskroś współczesny, chociaż nie pozbawiony zabiegów retorycznych, takich jak aliteracje czy różnego rodzaju powtórzenia. Figury te staram się w swoim przekładzie jak najwierniej oddawać, choć dopuszczam nieliczne odstępstwa np. co do powtarzającej się głoski (co zaznaczam każdorazowo w przypisach).

\footnotetext{
${ }^{22}$ S. Zabłocki, op. cit., s. 158.
} 


\section{POCIESZENIE DLA LIWII PO ŚMIERCI SYNA DRUZUSA}

Długo się wydawałaś szczęśliwa, matką Neronów

Zwana - już ci połowę tego imienia odjęto.

Oto czytasz żałobną tę pieśń dla Druzusa, Liwio,

Jeden $^{23}$ ostał się, który może nazywać cię matką.

I nie wywoła rozterki przykładna miłość do obu-

Kiedy syna ktoś wspomni, więcej nie spytasz go: „Który?”

Któż się waży granice rozpaczy twojej wyznaczyć?

Lub kto łzy się ośmieli z twego oblicza ocierać?

Ach, jak łatwo (jakkolwiek ten smutek wszystkich dotyka)

Słów podnoszących na duchu w cudzej nie szczędzić żałobie.

Jasne: „Cios cię dotknął, lecz minie szybko jak mgnienie,

Abyś mogła silniejszą stać się przez nieszczęść nawałę ${ }^{24 \%}$.

Młodo odszedł najwyższej czci godzien wzór obyczajów,

Pierwszym był wśród żołnierzy, pierwszym wśród obywateli.

On to niedawno, wrogom wydarłszy Alpy cieniste ${ }^{25}$,

Zyskał wojenną sławę w bitwach pod brata dowództwem.

On to dzikich Sykambrów ${ }^{26}$ i Swebów ${ }^{27}$ nieokrzesanych

Lud barbarzyński ujarzmił, do ucieczki zmuszając,

Tryumf ci, Rzymianinie, zgotował, jakiego dotąd

Nie oglądałeś, twą władzę szerząc po obcych ziemiach.

Losu swojego niepomna, zaczęłaś, matko, szykować

Dla Jowisza ofiary i dla walecznej bogini ${ }^{28}$;

Ojca Gradywa ${ }^{29}$ miałaś darami uczcić i wszystkich

Bogów, których pobożność czcić każe i prawo ludzkie.

Z matczyną dumą tryumfy prześwietne mu gotowałaś,

Może zdążyłaś się nawet już o wóz godny postarać ${ }^{30}$.

${ }^{23}$ Mowa o bracie Druzusa, Tyberiuszu Klaudiuszu Neronie, późniejszym cesarzu Tyberiuszu (14-37 r. n.e.).

${ }^{24}$ Ablativus cladibus tuis może pełnić dwojaką funkcję. Witlox skłania się ku znaczeniu porównawczemu: „silniejsza od twych nieszczęść”, ja jednak decyduję się na znaczenie przyczynowe.

${ }^{25} \mathrm{~W}$ wojnie z Retami i Windelikami.

${ }^{26}$ Plemię germańskie zamieszkałe nad Renem, na północ od Ubiów.

${ }^{27}$ Jeden z wielkich ludów germańskich, które pokonał Juliusz Cezar w wojnie z Ariowistem. Po klęsce pod Vesontio w 58 r. p.n.e. przez cały następny wiek toczyli ze zmiennym szczęściem walki z Rzymianami.

${ }^{28}$ Mowa o Minerwie.

${ }^{29}$ Przydomek Marsa, głównego patrona miasta, nadany mu przez armię rzymską. Określenie „ojciec" oprócz funkcji konwencjonalnego przydomka męskich bóstw wskazuje na pochodzenie narodu rzymskiego od synów Marsa.

${ }^{30}$ Zwycięski wódz odbywał w Rzymie tryumfalny pochód na czele swojego wojska, przy czym sam jechał na specjalnym rydwanie zaprzężonym w cztery białe konie. 
Zamiast tryumfów pogrzeb wyprawić będziesz musiała,

Zamiast wzgórza Jowisza ${ }^{31}$ grób zimny czeka Druzusa.

Myślą w przód wybiegałaś, wyobrażając już sobie

Powrót jego i radość, w oczach twych zdał się zwycięzcą:

„Zaraz syn mój przybędzie, tłum ujrzy me powitanie,

Zaraz będzie mi trzeba dary nieść dla Druzusa.

Wyjdę naprzeciw i będą po miastach mówić: »Szczęśliwa!«,

Usta przycisnę do jego szyi i oczu, i twarzy.

Taki będzie, tak przyjdzie, tak złączy się w pocałunku,

To mi opowie, tak sama pierwsza do niego przemówię".

Wielkiej oczekiwałaś radości: odrzuć nadzieję

Złudną, zaniechaj pogodnych myśli o synu, nieszczęsna.

Oto ta odrośl Cezara ${ }^{32}$, obecna w modlitwie za synów,

Uschła: rozpuść już, Liwio, włosy, jak zwyczaj dyktuje ${ }^{33}$.

Cóż ci twe obyczaje pomogą, tak nienaganne,

Skromne twe prowadzenie, miłość takiego męża?

Cóż, że twa obyczajność tak wiele ci dóbr przysporzyła,

Że wśród nich ona sama miejsce zajmuje ostatnie?

Cóż, że dusza twa czysta na ducha czasu nie zważa,

Żeś nieskalaną swą głowę ponad zbrodnie podniosła,

Żeś nie szkodziła nikomu, choć miałaś po temu sposobność,

Że nikt się lękać nie musiał nerwów, na wodzy trzymanych,

Żeś się nie posłużyła wpływami na forum ni w polu,

$\mathrm{Z}$ domu nie więcej wychodząc niż to kobiecie przystoi?

Takie niestety również zwycięża złośliwa Fortuna

Obyczaje. Na chwiejnym kole się znów dziś oparła.

Czuć nawet tu, jak się sroży, by czegoś z rąk nie wypuścić

W swej zachłanności. Wszędzie prawo w bezprawie obraca.

Jasna sprawa: wszak gdyby ostała się jedna żałobą

Liwia nietknięta, to władzę mniejszą by miała Fortuna.

Choćby się tak w sytuacji wszelakiej nie zachowywała,

Że nie zazdrościł nikt nigdy Liwii szczęścia - cóż z tego?

Przecież mówimy o domu Cezara ${ }^{34}$, który powinien

Stać ponad znojem człowieczym, niedoświadczony żałobą!

On to, boski opiekun, na wzgórzu najwyższym czuwając,

Godzien był w miejscu bezpiecznym sądzić o sprawach ludzi,

\footnotetext{
${ }^{31}$ Kapitol, na którym wodzowie odbywający tryumf składali ofiary Jowiszowi.

${ }^{32}$ Druzus nie był wprawdzie synem Augusta, ale przez większą część życia wychowywał się pod okiem ojczyma.

${ }^{33}$ Rozpuszczone włosy były charakterystyczną dla rzymskich kobiet oznaką żałoby.

${ }^{34} \mathrm{~W}$ oryginale: Caesaris adde domum - typowy dla Konsolatora przeskok myślowy, prowadzący do pochwały Cezara.
} 
Nikt nie powinien nad nim rozpaczać ni on nad nikim,

Ani sam się troskami martwić, które lud cierpi -

A widzieliśmy przecież, jak płakał po stracie siostrzeńca ${ }^{35}$ :

Jak po śmierci Druzusa, boleść ta była publiczną;

W jednym grobie pochował Agryppę $e^{36}$ i ciebie, Marcellu,

Tak że jedno to miejsce zięciów przyjęło obydwu;

Ledwie po śmierci Agryppy zamknęły się wrota grobowca,

Wnet obowiązek kazał siostrę ${ }^{37}$ pożegnać pogrzebem.

Teraz, po trzech już doznanych, najświeższa strata Druzusa

Jako czwarta napełnia smutkiem wielkiego Cezara.

Zatrzaśnijcie grobowiec, za długo otworem już stoi!

Zatrzaśnijcie go, Parki - dłużej nie godzi się zwlekać.

Świat ten już opuściłeś, Druzusie, na próżno wznosimy

Po raz ostatni tytuły ${ }^{38}$ - skargą niech będą na los twój.

Całe wieki by sobą wypełnić mogła ta żałość,

Trwać, napełniając smutkiem serca całego ludu.

Więcej byłeś niż jednym człowiekiem - w tobie odeszło

Wielu, cnót wszelkich wcielenie! Żadne cię z dóbr nie minęło.

Żadna z matek nie była płodniejszą od twej rodzicielki,

Która przez poród podwójny dobra przyniosła tak wiele.

Ach, gdzież znajdzie się para w tak wielu wam równa przymiotach,

Tak zgodna miłość braterska, w którą nikt wątpić by nie mógł?

Oto widzimy, jak Neron, wstrząśnięty brata odejściem,

Płacze, po twarzy bladością zdjętej włos rozpuściwszy,

Niepodobny do siebie, z obliczem ból zdradzającym:

Ach, jakiż smutek straszliwy całą twarz obejmuje!

$\mathrm{Ty}^{39}$ wszak w ostatniej godzinie widziałeś brata, gdy z życiem

Żegnał się, on zaś widział łzy twoje nad nim płynące,

${ }^{35}$ Chodzi o Marka Klaudiusza Marcellusa, najstarszego syna Oktawii i Gajusza Klaudiusza Marcellusa, który zmarł przedwcześnie w 23 r. p.n.e. Jako najbliższy męski krewny Augusta, a zarazem mąż jego córki Julii miał - w opinii publicznej - odziedziczyć tron cesarski. Śmierć dziewiętnastolatka chętnie przypisywano Liwii, starającej się uczynić spadkobiercą któregoś ze swoich synów.

${ }^{36}$ Marek Wipsaniusz Agryppa, wybitny dowódca wojskowy i kilkukrotny konsul, przyjaciel Augusta i drugi mąż jego córki Julii. Po śmierci Marcellusa (a może i wcześniej) był głównym pretendentem do odziedziczenia tronu. Po śmierci w 12 r. p.n.e. został pochowany w Mauzoleum Augusta.

${ }^{37}$ Oktawia, żona Gajusza Klaudiusza Marcellusa, a po owdowieniu Marka Antoniusza. Od niej wywodziła się większość członków dynastii julijsko-klaudyjskiej, m.in. cesarze Kaligula, Klaudiusz i Neron. Zmarła w 11 r. p.n.e.

${ }^{38}$ Tytuł konsula, którą to funkcję pełnił Druzus w 9 r. p.n.e., oraz nowo nabyty przydomek Germanika.

${ }^{39}$ Częsta w Pocieszeniu nagła zmiana adresata wypowiedzi - tu: z Druzusa na Tyberiusza. 
Czuł przed śmiercią, jak pierś twa do jego piersi przywiera, Trwał tak, w twoje oblicze oczy gasnące wbijając -

Oczy błękitne, mające pogrążyć się w śmierci otchłanie,

Oczy, które braterska ręka wnet miała zamknąć.

Matka tymczasem, nieszczęsna, nie mogła dotknąć ust syna

Ani do drżącej piersi członków ziębnących przycisnąć;

Ulatującej z ust duszy nie mogła z daleka pochwycićto

Ani włosów obciętych po twym ciele rozsypać.

$Z$ dala od niej zabity, gdy wojny odległe toczyłeś,

Większy niż sobie, Druzusie, zysk przyniosłeś ojczyźnie.

Łzy więc płyną z jej oczu jak nieraz śnieg miękki topnieje

W słońca promieniach, dotknięty wiosny rozgrzanym powiewem.

Skarży się teraz na los twój tak ciężki, ofiary wzgardzone,

Nieprzeliczone swe lata wini za nieszczęść nawałę.

Tak w cienistych gaikach Itysa $\mathrm{z}$ rodu trackiego ${ }^{41}$

Słodki ptak daulijski wciąż po dziś dzień opłakuje;

Tak lamenty Alkione ${ }^{42}$, wznoszone głosem bezsilnym,

Mórz wzburzonych nieczułe tonie na wskroś przenikają.

Tak żeście, ptaki, pieniami z swych piersi pokrytych pierzastym

Puchem $^{43}$, świeżo wyrosłym, syna Ojneusa ${ }^{44}$ chwaliły;

Tak płakała Klymene ${ }^{45}$, tak samo jej córki płakały,

Gdy z ojcowskiego zaprzęgu chłopiec spadł, z nieba rażony.

Stara się walczyć ze łzami, płynące wstrzymać, osuszać

Już wylane; z oczami bój toczy, w duszy się żaląc.

Znowu tryskają, a z oczu brzemiennych, we łzy urodzajnych

W dół po policzkach spływając, łono i pierś obmywają.

\footnotetext{
${ }^{40}$ Kiedy zbliżała się śmierć Rzymianina, ktoś z jego bliskich symbolicznie chwytał ustami duszę ulatującą przez usta umierającego.

${ }^{41}$ Tereus, król Tracji i Daulii, kilka lat po ślubie z tebańską królewną Prokne zakochał się w jej siostrze Filomeli. Zgwałcił szwagierkę, a następnie uwięził ją, uciąwszy język, by nie mogła się poskarżyć na swój los, żonie zaś oznajmił, że jej siostra nie żyje. Filomeli udało się jednak wyhaftować swoją historię na tkaninie, którą posłała siostrze w darze. Obie kobiety postanowiły zemścić się na Tereusie, zabijając jego synka Itysa i podając go ojcu do zjedzenia. Kiedy rozwścieczony Tereus ścigał kobiety, bogowie przemienili całą trójkę w ptaki: Prokne - w słowika, Filomelę - w jaskółkę, Tereusa zaś - w dudka.

${ }^{42}$ Alkione, córka Eole, chwaliła się, że są z mężem tak szczęsliwi jak Dzeus i Hera. Bogowie ukarali ją za to, zsyłając na Keyksa śmierć na morzu, tak jednak wzruszyły ich lamenty wdowy, że przemienili oboje małżonków w ptaki: Alkione - w zimorodka, a Keyksa - w mewę.

${ }^{43} \mathrm{~W}$ oryginale aliteracja: Sic plumosa novis plengentes pectora pennis.

${ }^{44}$ Meleager, syn Ojneusa, zakochany w Atalancie, przyznał jej prawo do skóry dzika zabitego w czasie łowów kalidońskich. Podczas kłótni, która się z tego powodu wywiązała, zabił swoich wujów, za co uśmierciła go własna matka, wrzucając do ognia głownię pozostawioną przez Mojry.

${ }^{45}$ Faeton, syn okeanidy Klymene, zginął na skutek upadku z rydwanu swego ojca Heliosa, którym powozil, aby udowodnić swoje boskie pochodzenie.
} 
Odwlekanie rozpaczy jedynie ją zwiększy; gdy wstrzymasz

Choćby na moment łez strumień, falą wytryśnie obfitszą ${ }^{46}$.

Wreszcie, gdy była już w stanie przez łzy dojść do głosu, wciąż walcząc,

$\mathrm{Z}$ płaczem te oto słowa, szlochem thumione, wyrzekła:

„Synu, połowo z dwu, których na świat ten wydałam, mój synu, dumo cnej matki, radości krótko trwająca - gdzie jesteś?

Lecz nie mogę już mówić o dwóch ani zwać cię połową, dumo (wciąż jeszcze) matki zacnej - synu, gdzie jesteś? ${ }^{47}$

Gdzieś jest z niedawną swą chwałą? Do grobu i ognia cię wiodą.

To są więc dary, którymi powrót twój mieliśmy uczcić?

Tak zatem ci się godziło przed matki stanąć obliczem?

Tak się matce godziło widzieć twój powrót do domu?

Nie wiem, czy wolno małżonce Cezara tak się odzywać,

Wątpić już jednak zaczynam w wielkich bogów istnienie.

Cóż bowiem ja zawiniłam? Czy kult którychś bóstw zaniedbałam?

Może przypadkiem komuś z niebian czci uchybiłam?

To jest zapłata za zbożność? Przytulam członki umarłe:

Z rąk mych swą własność wyrywa płomień i stos rozpalony.

Jak, nieszczęsna, wytrzymam twój widok, gdy leżysz przede mną?

Jak cię, synu, me ręce mają po śmierci namaścić?

Najnieszczęśliwsza z matek... Mam teraz uczcić i strzec cię,

Dłoń twą ugłaskać, przycisnąć usta do ust twoich chłodu?

Teraz dopiero cię matka konsulem ujrzy zwycięskim?

Tak, w ten sposób do domu niesiesz tak znaczne zaszczyty?

Rózeg pęk, który niedawno widziałam przed tobą, teraz

Widzę na znak żałoby odwrócony na pogrzeb.

Któż uwierzy? Dziś nadszedł ten dzień dla matki najsłodszy,

W którym syna nareszcie w chwale najwyższej ujrzała...

Już więc nie będę szczęśliwą? Wydarty jeden z Neronów

Matce - przesławny Druzus, dziada ${ }^{48}$ imieniem nazwany?

Więcej już moim nie będzie, nie nazwie mnie rodzicielką?

Więcej nie będę Druzusa matką i jego nie będzie?

Nigdy już, gdy doniosą, że Neron przybywa zwycięski,

Spytać nie będę mogła: „Starszy czy młodszy przybywa?”49

${ }^{46} \mathrm{~W}$ oryginale: In vires abiit flendi mora: plenior unda / defluit exigua siqua retenta mora. Zdanie problematyczne, można rozumieć również jako: „Odwlekanie płakania przekłada się na siły: większa fala przechodzi, jeśli jest wstrzymywana niewielką zwłoką”.

${ }^{47}$ Lament Liwii charakteryzują częste powtórzenia i przeskoki myślowe, podkreślające poruszenie cesarzowej.

${ }^{48}$ Ojcem Liwii był Marek Liwiusz Druzus Klaudian.

${ }^{49}$ Powtórzenie myśli z wersu 6. 
Dna sięgnęłam - jednego mam prawo matką się mienić,

Dzięki niemu jednemu zwać mnie nie będą bezdzietną ...

O, ja biedna! Struchlałam, aż dreszcz mnie przeszedł do szpiku:

Więcej nie powiem, że czegoś mogę w życiu być pewna.

Ten oto moim był przecież - a wzywa do troski o brata;

Boję się teraz wszystkiego, chociaż byłam odważna.

Obym przynajmniej umarła za twego życia, Neronie!

Zamknij me oczy, jak trzeba, duszę przechwyć ustami.

Ach, gdybyż dłonie złączone - Druzusa jedna i druga

Brata - me oczy po śmierci według zwyczaju domknęły!

Co się godzi, otrzymasz: we wspólnej spoczniemy mogile,

Wśród pradawnych przodków w grobie nie legniesz złożony ${ }^{50}$;

Prochy me z twymi prochami zmieszają i z kośćmi twoimi:

Niechże już Parka wyprzędzie dzień ów na prędkim wrzecionie!"

Więcej jeszcze się skarży, a łzy idą w ślad za słowami,

Płynąc znowu ku ustom ledwie zamkniętym po skardze.

Mało! Nawet to ciało, dopiero co matce wyrwane,

Prawie by, Liwio, pogrzebu pozbawione zostało.

Wojsko bowiem przywódcę pomiędzy orężem płonącym,

Wśród którego zginął, było gotowe ułożyć.

Oddać nie chcieli, lecz ciało czci godne brat im odebrał,

By Druzusa ojczyźnie zwrócić, jak się godziło.

Ciągną żałobne kondukty ku czci jego w rzymskich miasteczkach,

Które w swoim tryumfie miał - o, ironio! - przemierzać,

Które już dawniej odwiedził, gdy wojsko Retów ${ }^{51}$ rozbroił:

Ach! Jak mam, biedny, porównać pochód dzisiejszy do tamtych?

Konsul wstępuje do Rzymu, w ręku pęk rózeg złamanych...

Tak witamy zwycięzcę? Cóż by więc zrobił przegrany?

Dźwięk żałobnych kołatek dobiega z domu, którego

Pan tak raźnie ślubował oręż zdobyty poświęcićs2.

Jęczy miasto nieszczęsne, twarze wszystkich jednakie;

Czemuż min takich nie mogą ludy mieć nieprzyjacielskie?

Lud zagubiony swe domy zamyka i biega po mieście,

To tu, to tam łzy wylewa, jawnie albo w ukryciu.

W sądzie cisza, procesy milkną, nieme, bez świadków,

Nikt na całym forum w dumnej purpurze ${ }^{53}$ nie chodzi.

${ }^{50}$ Druzusa pochowano w Mauzoleum Augusta, a nie w grobowcu rodu klaudyjskiego.

${ }^{51}$ Lud zamieszkały w Alpach wschodnich i nad górnym Dunajem, na terenach dzisiejszego Tyrolu i północno-wschodniej Szwajcarii.

${ }^{52}$ Wódz wyruszający na wojnę ślubował poświęcić bóstwom broń, którą zdobył na wrogu.

${ }^{53}$ Toga praetexta, zdobiona purpurowym pasem, stanowiła strój urzędnika rzymskiego. Brak tego koloru na forum oznacza, że z powodu żałoby również urzędnicy zaniechali zwykłych obowiązków. 
Bóstwa się kryją w świątyniach, chowają okrutne oblicza,

I nie żądają kadzideł, które na stos trzeba zanieść;

Mury przybytków je chronią; wstydzą się w twarze czcicieli

Spojrzeć, ich nienawiści, słusznej skądinąd, się bojąc.

190

Oto ktoś z plebsu pobożnie za swoim potomkiem w potrzebie ${ }^{54}$

Drżące ramiona błagalnie wznosząc ku gwiazdom wysokim,

Już się chciał wstawić, lecz rzecze: „Ach, po cóż ofiary daremne

Mam przed ołtarz przynosić bogom nieistniejącym?

Przecież i Liwii modlitwa za syna ich nie wzruszyła,

O mnie więc Jowisz potężny bardziej miałby się troszczyć?"

Rzekł to i dary swe w gniewie porzucił miast ofiarować,

Serce zatwardził i modlitw próżnych zrazu zaniechał.

Z naprzeciwka tłum ciągnie, wśród łez zwilżających oblicza

Żaląc się, jakim jest ciosem strata konsula dla ludu.

Oczy zaczerwienione u wszystkich, bo wszyscy płaczemy ${ }^{55}$,

W pogrzebowym kondukcie nie brak żadnego ekwity.

Lament zanoszą na równi młodzieńcy i starcy, wiek każdy,

Rozpaczają auzońskie ${ }^{56}$ matki i córki auzońskie.

$\mathrm{Z}$ płaczem teraz niesiony na pomnik nagrobny zdobywcy

Wieniec laurowy powinien zdobić skronie zwycięskie.

Walczy młodzież gorliwa o zaszczyt dźwigania ciężaru

Mar, ofiarując ochoczo barki swe na tę służbę.

W słowach łzami skąpanych chwaliłeś, Cezarze, młodzieńca,

Kiedy w pół słowa ci rozpacz mowę żałobną przerwała.

205

Śmierci sobie życzyłeś ${ }^{57}$ (niech dopomogą bogowie!)

Takiej samej dla siebie, jeśli los da ci umrzeć.

Tobie się niebo należy! Ciebie do swego królestwa

Przyjmie władca piorunów - już się nie może doczekać!

To, czego Druzus pragnął, otrzymał: za czyny go chwalisz,

Sławą okryty umiera, cześć swą za śmierć odbierając.

Stos otaczają kohorty pod bronią, jak każe obyczaj;

Pieszy i jeździec wodzowi równo honory oddają.

Wciąż i wciąż cię od nowa wołają głosem donośnym,

Echem od skał się odbiwszy, krzyk do nas zaraz powraca.

\footnotetext{
${ }^{54} \mathrm{~W}$ oryginale aliteracja: de plebe pius pro paupere nato.

${ }^{55}$ Wers ten stanowi dodatkowy argument przeciwko autorstwu Owidiusza, który, przebywając na wygnaniu, nie mógł żadną miarą uczestniczyć w pogrzebie Druzusa.

${ }^{56}$ Ausones zamieszkiwali południową Italię, zanim podbili ją Rzymianie. Nazwy tej używano później jako erudycyjnego określenia najdawniejszych mieszkańców półwyspu.

${ }^{57}$ Życzenie sobie śmierci jest zwyczajowym elementem pogrzebowego lamentu (por. Il. XXIV 763).
} 
Wzdraga się sam ojciec Tyber wśród fal swych żółto barwionych ${ }^{58}$, Głowę chmurnie podnosząc w środku nurtu rzecznego.

Włos swój błękitny, spleciony z witkami wierzby i trzciną,

Mchem przeplatany, potężną dłonią zbiera z oblicza.

$\mathrm{Z}$ oczu łez pełnych prawdziwą ich rzekę naraz wypuszcza;

Już z wiekowego łożyska wodę wezbraną wylewa ${ }^{59}$.

Już miał ognia płomienie zagasić fal swych zalewem,

Ciało nietknięte ze sobą porywając w odmęty,

(Wody swe w miejscu wstrzymał i biegu do morza zaniechał,

Tak że całym swym nurtem stos mógłby zgasić z łatwością),

Jednak z pobliskiej świątyni, opodal Pola ${ }^{60}$ stojącej,

Mars ${ }^{61}$ się odezwał, te słowa mówiąc, sam łzami zalany:

Rzeka ma prawo się burzyć, lecz proszę, uspokój się, Tybrze;

$\mathrm{Z}$ losem się wygrać nie uda tobie ani nikomu.

Zginął będący moją własnością, zginął wśród broni,

W służbie ojczyzny dowodząc - koi ból ta świadomość.

Dałem, co dać mu mogłem: zwycięstwo dostał w udziale.

Jego sprawca odchodzi, ale trwać będzie zwycięstwo.

Raz próbowałem wyprosić u Kloto i obu jej siostrzyc ${ }^{62}$,

Które pewnymi palcami nić przędą nieubłaganą,

Aby jakimś sposobem podziemnych bagien ${ }^{63}$ uniknął

Remus, syn Ilii, wraz z bratem, który Rzym niegdyś założył ${ }^{64}$.

Jedna z sióstr trójcy mi rzekła: «Połowa twej prośby się spełni:

Jeden z braci to, czego żądasz dla obu, otrzyma.

Ten do ciebie należy, do Wenus zaś obu Cezarów ${ }^{65}$;

Tylko tych trzech się bogami stanie w mieście Marsowym».

Tak wyśpiewały boginie, więc porzuć opór daremny,

Tybrze, i przestań wstrzymywać ogień swoimi falami,

${ }^{58}$ Tyber często określany jest w rzymskiej poezji epitetem ,żółty” (flavus) ze względu na zabarwienie jego zamulonych wód.

${ }^{59} \mathrm{~W}$ oryginale aliteracja: adiectas alveus altus aquas. Ze względu na trudności translatorskie oddaję ją w przekładzie onomatopeiczną aliteracją, naśladującą odgłos burzących się, spienionych fal.

${ }^{60} \mathrm{~W}$ rejonie rozległego (ok. $2 \mathrm{~km}^{2}$ ) Pola Marsowego znajdowało się wiele świątyń.

${ }^{61}$ Mars, jako jeden z głównych patronów Rzymu, przemawia w obronie miasta, starając się uspokoić wzburzone bóstwo rzeczne.

${ }^{62}$ Mowa o Parkach: Klotho, Lachesis i Atropos.

${ }^{63}$ Hades tradycyjnie przedstawiano jako miejsce wilgotne i bagniste.

${ }^{64}$ Założyciel Rzymu Romulus został po śmierci deifikowany i czczono go odtąd jako Kwirynusa. W wersji Konsolatora to jego ojciec Mars prosił Parki o ocalenie od śmierci jego i jego brata. Synami Ilii nazywa Romulusa i Remusa również Owidiusz (Am. III 4, 40).

${ }^{65}$ Juliusz Cezar został po śmierci ubóstwiony. Taki sam los wróży Konsolator Augustowi - jak podaje, prosiła o to Wenus, od której według legendy wywodził się ród Juliuszów. 
Nie przeszkadzaj pochować młodzieńca wśród tylu zaszczytów.

Płyńże, posuwaj się naprzód, wody puściwszy w dół nurtu!"

Fale potężne posłusznie z powrotem wzdłuż prądu rozciąga,

Każąc im wrócić pod dach swój z głazów nadbrzeżnych wzniesiony.

Z ociąganiem ogień ogarną ${ }^{66}$ ciało czcigodne,

Dotykając leniwie mar niedawno złożonych.

Kiedy się jednak zajęło już drewno i strawa zmarłego,

Niebios sięgną, płomienie wznosząc wysoko ku gwiazdom,

Tak jak wśród wzgórz Herkulejskiej się Ety ogień zapalił,

Kiedy to boskie członki dano płomieniom na strawę ${ }^{67}$.

Ach! Oto płonie ideał męskiego piękna: sylwetka

Zgrabna, przyjemne oblicze, żywy charakter wraz płonie,

Ręce zwycięskie i usta wymowne, właściwe wodzowi,

Oraz serce - przestronne ducha wielkiego mieszkanie.

Płoną nadzieje wielu w tych samych płomieniach zarazem;

W tymże stosie spoczywa biedne serce matczyne.

Niechaj przetrwają czyny i sława wodza sprawnego;

To pozostanie, to tylko ujdzie płomieniom żarłocznym.

Stanie się częścią historii, wspominać go będą po wieki,

Swoją osobą zapewni temat dla pieśni genialnych.

Pomnik twój stanie na Rostrach z wyrytą zaszczytnie inskrypcją ${ }^{68}$,

A o śmierć twą, Druzusie, nas tylko będą obwiniać.

Ale dla ciebie, Germanio, nie znajdzie się żadna łaska:

Wkrótce, o barbarzyńco, karę za śmierć tę poniesiesz.

Obym mógł karki twych królów widzieć sinymi od więzów,

Poranionymi, a ręce sznurem niech będą związane,

Wreszcie niech drżą ze strachu ich twarze, a na oblicza

Nienawistne niech płyną łzy po twardych policzkach.

Tego ducha dzikiego, dumnego ze śmierci Druzusa

Dać trzeba będzie katowi, aby zgnił w lochu ponurym.

Stać będę nad nim z rozkoszą i okiem leniwym oglądać

Obnażone członki, okrutnie porozciągane.

Dzień ten, takie widoki niosący, niech jak najprędzej

Lśniąca od rosy Aurora wwiezie na koniach złocistych!

${ }^{66} \mathrm{~W}$ oryginale aliteracja: cunctata caput contingere. Polski przekład w połączeniu ze spondeiczną budową wersu oddaje leniwy ruch płomieni.

${ }^{67}$ Herkules, cierpiący męczarnie z powodu zatrutej szaty, został spalony żywcem na stosie wzniesionym w Ecie. Historię tę opowiada Seneka w tragedii Hercules Oetaeus.

${ }^{68}$ Znajdującą się na Forum Romanum mównicę nazywano Rostrami, ponieważ była u dołu ozdobiona dziobami okrętów (rostrum) zdobytych w 338 r. p.n.e. w bitwie pod Ancjum, podczas wojny z Latynami. Po śmierci Druzusa August rozkazał wznieść mu w tamtym miejscu pomnik, opisany wszystkimi tytułami poległego. 
Płaczą $^{69}$, migocząc zgodnie na niebie, i Ledy synowie ${ }^{70}$

Którzy w Rzymie na Forum cześć będą w świątyniach odbierać ${ }^{71}$.

Krótki żywot w udziale wielkiemu przypadł wodzowi,

Lecz zasługi dla państwa mierząc - w starości umarł.

Biada mi! Nigdy składanych tu ofiar Druzus nie ujrzy,

Nie przeczyta imienia swego u wrót świątynnych.

Głosem od łez zduszonym zapyta Neron ich nieraz:

„Czemuż, o boscy bracia, stoję bez brata przy boku?”

Wolą twą było, Druzusie, nie wracać bez palmy zwycięstwa;

Oto należny od losu dar twój: byłeś zwycięzcą.

Teraz nie mamy konsula, nie mamy wodza - zwycięzcy:

W całym się mieście żałość dotkliwa rozpanoszyła ${ }^{72}$.

Rozpacz na twarzach przyjaciół z włosami rozpuszczonymi...

Cały lud, Druzusie, wierny ci jest w twym nieszczęściu.

Z tłumu ktoś nagle wykrzyknie, ramiona ku tobie kierując:

„Czemuż beze mnie odchodzisz, czemuż bez towarzysza?”

Cóż mam o tobie powiedzieć, czcigodna Druzusa małżonko ${ }^{73}$,

Równa godnością teściowej, matce Druzusa, synowo?

Para z was była dobrana: z młodzieńców najodważniejszy

I małżonka troskliwa godna męża dzielnego.

Ty, najpierwsza wśród kobiet, wydajesz się, córko Cezara,

Równą być nawet przesławnej żonie wielkiego Jowisza.

Ty, prawowita małżonko, miłości jedyna, ostatnia,

Tyś odpocznieniem mu była, kiedy wracał strudzony.

Skargą ostatnią przed śmiercią mu była twa nieobecność,

W twoje się imię ułożył język w ustach stygnący.

Wraca do ciebie, nieszczęsnej, nie tak, jak sam ci obiecał,

Jak się w pole wyprawiał, wraca do ciebie nie twoim,

Już o zagładzie Sykambrów nie będzie ci mógł opowiedzieć

Ani jak grzbiety Swebów poddał pod ostrza swych mieczy,

Ani ci już nie wyliczy nazw sławnych rzek i pasm górskich,

Ani wszelkich miejsc obcych, które gdzieś w świecie widział.

${ }^{69}$ Kolejny nagły przeskok myślowy, w oryginale zaznaczony zwrotem: adice Ledaeos. Dioskurowie stanowią tu kolejny, po Tybrze i Marsie, przykład boskich patronów Rzymu, opłakujących śmierć wodza.

${ }^{70}$ Kastor i Polluks doznawali czci jako gwiazdy w konstelacji Bliźniąt.

${ }^{71}$ Wzmiankę o świątyni Dioskurów próbowano wykorzystać jako wskazówkę co do daty powstania Pocieszenia, wydaje się jednak, że poeta, posługując się gerundivum (templaque Romano conspicienda foro), nie miał na myśli żadnej konkretnej budowli.

${ }^{72}$ Żałoba zostaje tu niemal spersonifikowana - w oryginale: invenit tota maeror in Urbe locum.

${ }^{73}$ Żoną Druzusa była Antonia Młodsza, córka Marka Antoniusza i Oktawii Młodszej, siostry Augusta. 
Wraca do ciebie już tylko wystygłe ciało bez życia,

Leży teraz na marach sam i nie możesz go objąć.

Dokąd cię nosi, że w szale swe włosy z głowy wyrywasz?

Dokąd się miotasz? Dlaczego dłoń twa szarpie policzki?

Tak Andromacha szalała, gdy mąż jej, za wozem się wlokąc,

Cały we krwi skąpany, konie przejmował popłochem ${ }^{74}$.

Tak Euadne szalała, gdy twarz swą nieporuszoną

Zwrócił ku błyskawicom lśniącym mąż jej Kapaneus ${ }^{75}$.

Czemuż z bólu już błagasz o śmierć i dzieci przytulasz -

Ślady, które ci Druzus jako jedyne zostawił?

I już tylko cię we śnie nawiedza zjawa fałszywa,

Tobie się zaś wydaje Druzus być przy twym boku,

Sięgasz czym prędzej ręką w nadziei, że znów go tam znajdziesz,

Szukasz w pustej już części łoża, na której on sypiał.

On zaś, jak słusznie wierzymy, w krainie uświęconej

Wśród uwieńczonych przodków znajdzie się wkrótce w gościnie.

Tam, promieniejąc, poczwórnym powozić będzie rydwanem

Jako chluba przodków matki i ojca na równi,

W szatach iście królewskich, w powozie z kości słoniowej,

Przyozdobiony triumfalnym wieńcem laurowym na skroniach.

Godnie przyjmą młodzieńca niosącego trofea

Wojny germańskiej i sławę z władzą konsula związaną.

Cieszyć się będą z przydomka, na który w pełni zasłużył,

Który jako jedyną ${ }^{76} z$ dobycz wyrwał wrogowi.

$\mathrm{Z}$ trudem uwierzą, że tyle osiągnął człowiek tak młody:

Przecież na wielkie czyny lat wielu ludziom potrzeba!

One będą musiały go wynieść, o matko najlepsza,

Ponad niebiosa i łzy twe suszyć będą musiały.

Pani, godna tych, których przed laty zrodził wiek złoty,

Godna wodzów wśród synów, godna wodza za męża.

Bacz, co się godzi matce Druzusa i matce Nerona,

Bacz na to, kiedy o świcie z łoża swego powstajesz.

Co innego przystoi ludowi i świata światłości -

Oto, z jakim się trudem musi cesarski dom mierzyć.

${ }^{74}$ Po śmierci Hektora Achilles przywiązał jego ciało do swojego rydwanu i włóczył je wokół murów Troi.

${ }^{75}$ Kapaneus był jednym z siedmiu wodzów walczących przeciw Tebom. Chełpił się, że zburzy miasto nawet wbrew woli Dzeusa, który za karę poraził go piorunem.

${ }^{76}$ Myśl ta pozornie tylko przeczy wersom 335-336. Autor chce prawdopodobnie zaznaczyć, że jedyną korzyścią, jaką wyniesie dla siebie Druzus ze zdobyczy, o które wzbogacił Rzym, będzie nieśmiertelna chwała. 
Los cię na wysokościach postawił i zaszczytnego

Miejsca bronić nakazał: Liwio, wytrzymaj ten ciężar!

Oczy i uszy ku tobie zwracamy, widzimy, co czynisz,

Żadne się słowo, rzucone z ust cesarskich, nie skryje.

Zostań na swych wyżynach i wznieś się ponad swą rozpacz,

Ducha niezłamanego nie trać - wszak to potrafisz!

Czyż jest lepsza droga, by cnót twych znaleźć przykłady,

Niż kiedy obowiązek pełnisz rzymskiej władczyni?

Dybie los na każdego, na wszystkich czeka przewoźnik

Chciwy, ledwie wystarcza łódź jedna dla tłumu całego.

Wszyscy tam zdążamy, do końca wspólnego dążymy,

Prawa swe w całym świecie śmierć chce ${ }^{77}$ wprowadzić ponura.

Spójrz, oto przepowiedziano potrójny świata upadek:

Śmierć już postanowiona niebu, ziemi i morzu.

Skoro tak wielka zagłada nad światem wisi, na siebie

Zwróć swoje oczy i głośno własne krzywdy roztrząsaj.

Pierwszym spośród młodych za życia był, ludu nadzieją,

Chlubą najwyższą dla rodu, który na świat go wydał.

Śmiertelnikiem był jednak, nie mogłaś więc czuć się bezpieczną,

Kiedy syn twój najdroższy boje zaciekłe prowadził.

Życie dano nam jako pożyczkę i choć bez odsetek

Dano, nieznany jest termin, kiedy trzeba ją zwrócić.

Niesprawiedliwie przydziela Fortuna ludziom czas życia,

Nieraz młodzieńców zabiera, starców przy życiu zostawia.

Rzuca się, miota w swym szale, po całym świecie się ciska ${ }^{78}$,

Sama ślepa, na ślepych koniach tryumfy odbywa.

Przestań nieubłaganą boginię drażnić skargami,

Przestań już niepokoić serce wszechmocnej władczyni.

Tylko bowiem tym razem przychodzi do ciebie z boleścią,

Nieraz ci przecież w twych sprawach jak przyjaciółka sprzyjała:

W tym, żeś się z wysokiego zrodziła rodu, żeś synów

Dwu na ten świat wydała, mężem twym zaś jest Jowisz ${ }^{79}$,

Że, ujarzmiwszy narody, do ciebie zawsze powraca

Cezar i niezwyciężoną ręką wojny wygrywa,

$\dot{Z}$ e Neronowie spełniali matczyne sny i nadzieje,

Że nieprzyjaciół aż tylu, wspólnie dowodząc, podbili:

\footnotetext{
${ }^{77}$ Śmierć była jednym ze zjawisk, które rzymska religia szczególnie chętnie personifikowała.

${ }^{78}$ Myśl podobna do wersu 53.

${ }^{79} \mathrm{Już} \mathrm{za} \mathrm{czasów} \mathrm{Augusta} \mathrm{utożsamienie} \mathrm{cesarza} \mathrm{z} \mathrm{bogiem} \mathrm{stawało} \mathrm{się} \mathrm{powszechną} \mathrm{formą} \mathrm{czci.}$ Porównanie Cezara z władcą bogów było szczególnie kuszącą możliwością.
} 
Ren i alpejskie doliny, Isarka ${ }^{80}$, o czym świadczą

Wody o barwie zmienionej, czarną posoką skażone.

Wartki Dunaj i Daka ${ }^{81}$, mieszkańca świata rubieży,

Apulijczyka $^{82}$ (dla niego krótka jest droga do Pontu ${ }^{83}$ ),

Tchórzliwego Armena, Dalmatę ${ }^{84}$ posłusznego,

Pannończyków ${ }^{85}$, po szczytach górskich porozpraszanych,

390

Oraz świat germański, nieznany wcześniej Rzymowi.

Patrz, ile mniejsza od zasług jedna ta zbrodnia Fortuny!

$Z$ dala po nim w dodatku płakałaś ${ }^{86}$ i nie musiały

Oczy twe na wpół martwych oczu syna oglądać,

Przez to wolniej do serca biednego smutek docierał,

Skoro najpierw musiałaś o żałobie usłyszeć.

Przy tym niepokój karmiony wieściami o niebezpieczeństwach

Znacznie żałobę wyprzedził - słysząc je, drżałaś ze strachu.

Nie spadł więc na twe serce znienacka cios niespodziany,

Krok po kroku się zbliżał, troską ułagodzony.

Jowisz złowróżbną zapowiedź krwawego losu ci zesłał,

Dłonią swą błyskawicową trzy świątynie trafiając:

Nocą poraził przybytki Junony wielmożnej, Minerwy

Mężnej i pałac Cezara ${ }^{87}$, chociaż ten nic nie zawinił.

Mówią, że nawet już gwiazdy niebiosa opuściły,

Sama zaś Światło Niosąca ${ }^{88}$ z dróg swych zwykłych zniknęła -

Światło Niosąca nikomu na świecie nie zajaśniała,

Tak że bez gwiazdy porannej nadszedł dzień niespodzianie.

Znak ten ziemi ogłosił, że grozi jej gwiazdy upadek

I że się w wodzie Styksu światłość ma świata zanurzyć.

Ciebie zaś, który przy życiu zostałeś, pociecho nieszczęsnej

Matki, błagam - staruszkiem daj jej się kiedyś oglądać

Przeżyj długie lata za brata, jak i za siebie -

Wraz ze swym synem starcem niech żyje matka sędziwa!

${ }^{80}$ Isarkowie zamieszkiwali tereny nad Isarą, lewym dopływem Rodanu, uchodzącym do niego w okolicach Walencji.

${ }^{81}$ Dacją nazywano krainę położoną na lewym brzegu Dunaju, obejmujące tereny dzisiejszych Węgier i Rumunii.

${ }^{82}$ Apulus to nazwa miasta w Dacji.

${ }^{83}$ Pontem nazywali Rzymianie tereny nad Morzem Czarnym.

${ }^{84}$ Dalmaci zamieszkiwali wschodnie wybrzeże Adriatyku.

${ }^{85}$ Późniejsza rzymska prowincja Pannonia zajmowała tereny między Dunajem a Sawą.

${ }^{86}$ Myśl ta stoi w sprzeczności z wersami 95-96, w których Konsolator wyraża współczucie spowodowane faktem, że matka nie mogła być blisko syna w momencie śmierci.

${ }^{87}$ Ponieważ Konsolator już wcześniej traktuje Cezara jako ziemskiego boga, również jego dom zalicza do świątyń.

${ }^{88}$ Gwiazdę Poranną nazywa tu Konsolator przydomkiem Lucifer. 
Błagam, niech się to spełni! Jeżeli bóg zechce przebaczyć

To, co było, to nowe da prócz Druzusa radości.

Ty jednak tak wielkiemu cierpieniu potrafisz się poddać,

Nie przyjmując już więcej strawy? O, zgubna dzielności!

Ledwie ci też już zostały nieliczne życia godziny,

Kiedy to - mimo oporu - przyszedł ci Cezar z pomocą,

W prośby uderzył, dołączył o powinnościach słów kilka,

Gardło wyschnięte na koniec zwilżył ci, wodę wlewając.

Także syn się wykazał nie mniejszą troską o matkę:

Prośby swe głosem przymilnym wnosi, nie bez słuszności.

Męża i syna starania $\mathrm{z}$ wdzięcznością wszyscy przyjmują;

Męża i syna ${ }^{89}$ zasługą, Liwio, żeś wciąż jest wśród żywych.

Łzy powstrzymaj, bo one nie wrócą życiu już tego,

Kogo raz w swojej łodzi gościł ponury przewoźnik.

Wszak tylu braci, sióstr tyle Hektora opłakiwało

Razem z ojcem i żoną, z synkiem Astianaksem

Oraz matką sędziwą, on jednak, w płomienie rzucony,

Jako zjawa już nie mógł Styksu przepłynąć z powrotem.

O tym się też przekonała Tetyda, bo kości Achilla,

Miast burzyciela, spalone nadal leżą pod Troją.

Siostra matki Panope błękitny warkocz dla niego

Rozpuściła, podnosząc fale potężne od płaczu,

$\mathrm{Z}$ nią wraz sióstr jej setka, a nawet sama sędziwa

Okeanosa małżonka z ojcem Okeanosem,

A najbardziej Tetyda - lecz ani ona, ni reszta

Nie zmieniła tragicznych boga chciwego wyroków.

Po cóż te dawne historie wspominać ${ }^{90}$ ? Płakała Oktawia

Za Marcellem ${ }^{91}$, rozpaczał Cezar przed ludem za nimi ${ }^{92}$.

Lecz prawa śmierci się nie da odmienić ani uniknąć,

Odmierzonych już nici ręka niczyja nie wstrzyma.

Gdyby jemu samemu z cienistych brzegów Awernu ${ }^{93}$

Wolno było tu przybyć, mężnie by wyrzekł te słowa:

„Po cóż lata me liczyć? Dojrzalszy byłem za życia!

Starcem czynią zasługi ${ }^{94}$ - czyny powinnaś wyliczać,

One niech życie wypełnią, nie lata z wolna płynące,

Tych bowiem moim wrogom sporo przypadło w udziale.

\footnotetext{
${ }^{89} \mathrm{~W}$ oryginale anafora: coniugis et nati.

${ }^{90}$ Od przykładów mitycznych Konsolator przechodzi do niedawnych śmierci w rodzinie Augusta.

${ }^{91}$ Patrz przypis 10.

${ }^{92}$ Patrz przypis 12.

${ }^{93}$ Jedna z rzek w Hadesie.

${ }^{94}$ Powtórzenie myśli z wersu 286.
} 
Tego nas Neronowie uczyli z dziada, pradziada

(Dwóch dziadów w roli wodzów wojnę punicką wygrało ${ }^{95}$ ),

Tego nas uczy dom ten: Cezara i mój - dzięki tobie;

Oto koniec żywota, który przyjść musiał, matko.

Chociaż same wystarczą za siebie, nie brak zasługom

I chwały, matko - wszak widzisz obok imienia tytuły.

Oto czytają, że byłem konsulem i dalekiego

Kraju Germanów pogromcą - tam za lud swój zginąłem.

Skronie zwycięskie mi laurem uwieńczą Apollińskim,

Sam nawet słyszę procesje na mym pogrzebie kroczące:

Pochód dobrze znajomy żołnierzy i dary królewskie

Oraz wszystkie miasteczka wyczytywane po nazwach;

Widzę, z jakim oddaniem dźwigała mnie owa młodzież,

Która wokół mar moich licznie się zgromadziła.

Zasłużyłem na koniec na słowa pochwały z Cezara

Ust uświęconych i za mną łzy z boskich oczu płynęły.

Miałby się więc ktoś nade mną użalać? Łzy już powstrzymaj!

O to cię proszę ja, który sprawcą ci jestem rozpaczy".

Tak czuje Druzus, o ile cokolwiek czuć może w ciemnościach,

Więc o tak wielkim mężu nie miej niższego mniemania.

Wciąż masz jeszcze syna, na którym się wielu wzoruje -

Oby żył długo! - z twych dzieci starsze więc żyje bezpiecznie;

Masz małżonka, ostoję ludzkości - gdy on ma się dobrze,

Liwio, nie godzi się, aby dom wasz pozostał w żałobie.

\section{CONSOLATIO AD LIVIAM - A POLISH TRANSLATION}

Sum mary

Consolatio ad Liviam is a poem written in elegiac couplets at the beginning of $1^{\text {st }}$ century $\mathrm{AD}$ by an anonymous author. Although the text used to be attributed to Ovid until as late as $16^{\text {th }}$ century, its artistic level, historical context and meta- as well as intertextual hints almost certainly disprove his authorship. While not exceptionally remarkable as a piece of literature, the Consolatio seems to be of a certain interest from the historical point of view and to bring a valuable image of the Augustus' entourage as well as funeral rites. It is also a noteworthy example of a combination between two literary traditions, namely those of consolatio and epicedion. Therefore, a first Polish translation should be useful for philologists and, more significantly, historians, who not always have obtained the knowledge of Latin sufficient to read ancient poetry. A pseudo-isometrical translation has been chosen, in order to compromise the Roman colouring with the metrical requirements of the Polish language.

\footnotetext{
${ }^{95}$ Appiusz Klaudiusz Kaudeks był wodzem w pierwszej, a Gajusz Klaudiusz Neron w drugiej wojnie punickiej.
} 


\section{BIBLIOGRAFIA}

Tekst, przekłady, komentarze

Baehrens E., Poetae Latini Minores, t. 1, Leipzig 1879.

Lenz F.W., P. Ovidii Nasonis „Halieutica”, Fragmenta, Nux. „Incerti Consolatio ad Liviam”, Torino - Paravia 1939.

Mitterfels R. H., Pseudoovidiana, II: Consolatio ad Liviam, Mitterfels Selbstverl 1982.

Rupprecht H., Consolatio ad Liviam - Trostgedicht für Livia. Lateinischer Text mit Einleitung Übersetzung, kurzen Erläuterungen und Nachwort, Mitterfels 1982.

Schoonhoven H., Elegiae in Maecenatem: prolegomena, text and commentary, Groningen 1980.

Witlox A., Consolatio ad Liviam, prolegomenis, commentario exegetico, indice instructa, Maastricht 1934.

\section{Literatura sekundarna}

Bickel E., De Consolatione ad Liviam pro Claudio usurpatore Iuliani scripta, RhM 93, 1950, 193-227.

Danesi Marioni G., Suggestioni ovidiane e senecane nella „Consolatio ad Liviam”, A\&R XXXIII, 1983, 19-26.

Danesi Marioni G., Un problema testuale nella prima epistola delle Heroides e la „Consolatio ad Liviam”, „Prometheus” XIII, 1987, 13-22.

Enk P.J., L'énigme des Élégies sur Mécène, Mn. IX, 1941, 225-237.

Fraschetti A., Indice analitico della Consolatio ad Liviam Augustam de morte Drusi Neronis filii eius qui in Germania de morbo periit, MEFRA CVIII 1, 1996,191-239.

Holland R., Zu herrenlosen lateinischen Gedichten, PhW 1925, 140-144.

Lenz F. W., Consolatio ad Liviam 319-322, „Eranos” LV, 1957, 202-203.

Morel W., Zur Consolatio ad Liviam, „Hermes” LX, 1925, 493-494.

Richmond I., Consolatio ad Liviam 279-280, „Mnemosyne” XXXII, 1979, 176.

Rose H. J., Some passages of latin poets: Consolatio ad Liviam 379 Vollmer., HSPh 1936, 8-9.

Schlegelmilch U., Was ist und wovon handelt die Consolatio ad Liviam?, WJA XXIX, 2005, 151-184.

Schoonhoven H., Another excerpt from the „Consolatio ad Liviam”, „Mnemosyne” XXXVII, 1984, 147-148.

Schoonhoven H., ...si parua licet componere magnis (A note on the new Gallus papyrus, 11.3-5), ZPE LIII, 1983, 73-78.

Schrijvers P. H., A propos de la datation de la „,Consolatio ad Liviam”, „Mnemosyne” XLI, 1988, 381-384.

Schumacher T., „Elegiae in Maecenatem. Consolatio ad Liviam”. Stilkritische Untersuchungen und Datierung zweier unter Vergils und Ovids Namen überlieferten Gedichte, Bonn 1946.

\section{Literatura pomocnicza}

Brill's Encyclopaedia of the Ancient World New Pauly, t. 3, red. H. Cancik, H. Schneider, Leiden - Boston 2003. Claudius: Nero C. Drusus, 399-400.

Brill's Encyclopaedia of the Ancient World New Pauly, t. 3, red. H. Cancik, H. Schneider, Leiden - Boston 2003. Consolatio, 704-705.

Esteve-Forriol J., Die Trauer und Trostgedichte in der römischen Literatur, Diss. Munich 1962. Definition der Begriffe „Epikedion” und „, Consolatio”, 20-25.

Grant M., Hazel J., Kto jest kim w mitologii klasycznej, przeł. M. Michowski, Poznań 2000.

Małunowicz L., Co to jest konsolacja?, „Eos” LVII, 1967/68, 69-78.

Piszczek Z. (red.), Mała encyklopedia kultury antycznej, Warszawa 1988.

Purcell N., Livia and the womanhood of Rome, PCPhS XXXII, 1986, 78-105

Wikarjak J., Polskie przektady „Eneidy”, SPhP 3, 1977, 91-173.

Zabłocki S., Antyczne epicedium i elegia żałobna, Wrocław 1965. 